\title{
Pękanie zimne stali spawanej w środowisku wodnym
}

\section{Cold cracking of steel welded in water environment}

\section{Streszczenie}

W artykule scharakteryzowano zagrożenia spawalności stali konstrukcyjnych związane z przeniesieniem spawania do środowiska wodnego. Przedstawiono stan wiedzy oraz wyniki własnych prac badawczych dotyczących wpływu warunków i parametrów spawania pod wodą na wrażliwość do pękania zimnego stali konstrukcyjnych. Zwrócono uwagę na to, że pomimo znaczącej liczby publikacji wciąż wiele istotnych zagadnień pozostaje nierozwiązanych.

\section{Wstęp}

Woda jest środowiskiem spawania oddziałującym niekorzystnie na większość czynników mogących spowodować pękanie zimne [1, 2]:

- obecność kruchych struktur hartowniczych,

- koncentracja wodoru,

- wartość naprężeń pozostających,

- skład chemiczny spoin i obecność wtrąceń niemetalicznych oraz wydzieleń,

- działanie karbu.

Przeniesienie procesu spawania do środowiska wodnego powoduje przede wszystkim zwiększenie zawartości wodoru dyfundującego $\mathrm{w}$ stopiwie oraz

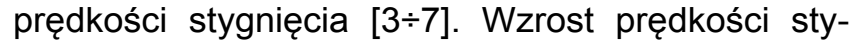
gnięcia przyczynia się z kolei do formowania się kruchych struktur i wzrostu wartości naprężeń pozostających [1, 2].

Podstawowa klasyfikacja procesów spawania pod wodą dzieli je na metody mokre i suche. Metody suche można w dalszej kolejności podzielić na izoba-

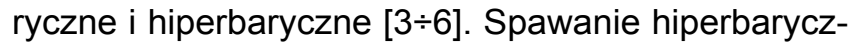
ne realizuje się w warunkach podwyższonego ciśnienia gazu wypychającego wodę $z$ obszaru spawania

Dr inż. Dariusz Fydrych - Politechnika Gdańska.

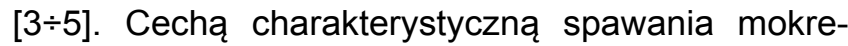
go jest bezpośredni kontakt nurka-spawacza, elektrody i materiału rodzimego $z$ wodą. Wariantem pośrednim jest metoda lokalnej komory suchej [24], polegająca na miejscowym odizolowaniu miejsca spawania od wody $[5,8,9]$. Spawanie pod wodą realizuje się zazwyczaj typowymi procesami spawalniczymi. Możliwości zastosowania poszczególnych procesów w różnych warunkach spawania podwodnego zestawiono $\mathrm{w}$ tablicy $\mathrm{I}$.

Tablica I. Możliwość zastosowania procesów spajania w środowisku wodnym $[3 \div 10]$

Table I. Possibility of application of welding processes in water environment $[3 \div 10]$

\begin{tabular}{|l|c|c|c|}
\hline \multicolumn{1}{|c|}{ Proces } & $\begin{array}{c}\text { Spawanie } \\
\text { suche }\end{array}$ & $\begin{array}{c}\text { Spawanie } \\
\text { mokre }\end{array}$ & $\begin{array}{c}\text { Spawanie } \\
\text { metodą } \\
\text { lokalnej } \\
\text { komory }\end{array}$ \\
\hline MMA (111) & tak & tak & możliwe \\
\hline SAW (121) & tak & tak & nie \\
\hline MIG/MAG (131/135) & tak & możliwe & tak \\
\hline FCAW (136/138) & tak & tak & tak \\
\hline FCAW-S (114) & możliwe & tak & możliwe \\
\hline Spawanie plazmowe (15) & możliwe & nie & możliwe \\
\hline Spawanie laserowe (751) & możliwe & nie & tak \\
\hline Zgrzewanie tarciowe (41) & tak & tak & nie \\
\hline Zgrzewanie wybuchowe (441) & nie & tak & nie \\
\hline Przypawanie kołków (78) & możliwe & tak & możliwe \\
\hline
\end{tabular}


Tablica II. Typowe ilości wodoru dyfundującego w stopiwie przy spa-

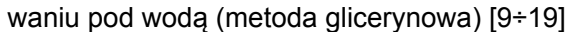

Table II. Typical values of diffusible hydrogen amount in deposited

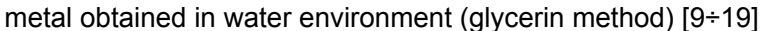

\begin{tabular}{|l|c|}
\hline \multicolumn{1}{|c|}{ Proces spawania } & $\begin{array}{l}\text { Ilość wodoru dyfundujące- } \\
\text { go w stopiwie, ml/100 g Fe }\end{array}$ \\
\hline $\begin{array}{l}\text { Spawanie mokre elektrodami } \\
\text { otulonymi rutylowymi }\end{array}$ & $45 \div 87$ \\
\hline $\begin{array}{l}\text { Spawanie mokre elektrodami } \\
\text { otulonymi utleniającymi }\end{array}$ & 13 \\
\hline $\begin{array}{l}\text { Spawanie mokre elektrodami } \\
\text { otulonymi zasadowymi }\end{array}$ & $35 \div 45$ \\
\hline Spawanie mokre MAG & poniżej 30 \\
\hline $\begin{array}{l}\text { Spawanie mokre drutem } \\
\text { samoosłonowym }\end{array}$ & $25 \div 44$ \\
\hline Spawanie mokre SAW & 50 \\
\hline $\begin{array}{l}\text { Spawanie metodą lokalnej komory } \\
\text { suchej MAG (C1) }\end{array}$ & $10 \div 20$ \\
\hline
\end{tabular}

Środowisko spawania stanowi potencjalne źródło wodoru. Badania zawartości wodoru dyfundującego w stopiwie wykazują, że procesy spawania pod wodą generują znacznie większą jego ilość niż spawanie w powietrzu. W tablicy II przedstawiono typowe zakresy nawodorowania stopiwa uzyskanego podczas spawania podwodnego.

Istotnym czynnikiem wpływającym na prędkość stygnięcia złączy spawanych pod wodą jest wymiana ciepła z otoczeniem przez konwekcję. Współczynnik wymiany ciepła z otoczeniem jest duży $\mathrm{i}$ - w zależności od typu wrzenia wody na powierzchni granicznej spawanego elementu i pozycji spawania - może być nawet 100 razy większy niż dla spawania w powietrzu [6]. Grubość materiału spawanego, podobnie jak przy spawaniu w powietrzu, ma istotny wpływ na prędkość stygnięcia. Stwierdzono, że przy spawaniu pod wodą blach o grubości $6 \mathrm{~mm}$ prędkość stygnięcia jest 12 razy większa niż w środowisku powietrznym, a blach o grubości $19 \mathrm{~mm}$ tylko 3 razy [6].

Zwiększoną skłonnością do tworzenia pęknięć zimnych charakteryzują się złącza wykonane w warunkach spawania mokrego, suchego hiperbarycznego i metodą lokalnej komory suchej $[3,4]$. Do określania wrażliwości na pękanie zimne złączy wykonanych pod wodą stosowano do tej pory zarówno próby technologiczne: Tekken i CTS [11, 12, 20 $\div 22]$, jak i próby z regulowany-

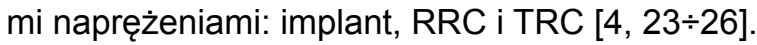

\section{Spawanie mokre elektrodami otulonymi}

Spośród metod spawania mokrego najczęściej stosowane jest spawanie ręczne elektrodami otulony$\mathrm{mi}[3 \div 7]$. Zazwyczaj stosuje się elektrody z otuliną rutylową. Ponieważ spawanie odbywa się bezpośrednio w wodzie, złącza charakteryzują się wysoką skłonnością do tworzenia pęknięć zimnych. Pęknięcia powstają nawet $\mathrm{w}$ stalach o niskim równoważniku węgla
$\mathrm{C}_{\mathrm{e}}=0,3 \%$ [20]. W złączach ze stali niskowęglowej stwierdzono wzrost twardości struktury do wartości $350 \div 400 \mathrm{HV}$ oraz występowanie licznych mikropęknięć wodorowych [20, 29]. Z rysunku 1 wynika, że czasy stygnięcia złączy są krótsze od czasów stygnięcia w środowisku powietrznym. Poza tym wzrost ilości wprowadzonego ciepła w pozycji podolnej w mniejszym stopniu wpływa na wzrost czasu stygnięcia $\mathrm{t}_{815}$, niż $\mathrm{w}$ przypadku spawania w środowisku powietrznym. Czas stygnięcia złączy wykonanych w pozycjach pionowych nie zależy od ilości wprowadzonego ciepła, co tłumaczy się powstawaniem silniejszych prądów konwekcyjnych [4].

llość wodoru dyfundującego w stopiwie zależy od ciśnienia wody, a więc od głębokości spawania $[24,27,30]$. Badania wykonane elektrodami $z$ otuliną rutylową wykazują, że zawartość wodoru w stopiwie nie zależy od stopnia jej zawilgocenia i zastosowanej warstwy ochronnej (rys. 2) [6, 14]. Dzięki zastosowaniu elektrod $\mathrm{z}$ otuliną utleniającą możliwe jest obniżenie zawartości wodoru dyfundującego do ok. $13 \mathrm{ml} / 100 \mathrm{~g} \mathrm{Fe} \mathrm{[15].} \mathrm{Wyniki} \mathrm{badań} \mathrm{dotyczących}$ wpływu ilości wprowadzonego ciepła są sprzeczne (rys. 3 i 4). Z wykresów wynika ponadto, że regulacja parametrów spawania nie zmniejszy zawartości wodoru do wartości, która zabezpieczałaby złącze przed powstawaniem pęknięć. Wzrost natężenia prądu spawania powoduje wzrost ilości wodoru w złączu (rys. 5). Istotny wpływ na to zjawisko wywiera również biegunowość spawania. Stopień nawodorowania stopiwa jest niższy przy biegunowości ujemnej. Wynika to z mechanizmu wnikania wodoru do ciekłego metalu. Przy biegunowości dodatniej wodór wnika bezpośrednio do jeziorka, natomiast w przeciwnym przypadku jest przenoszony do jeziorka w kroplach metalu [15].

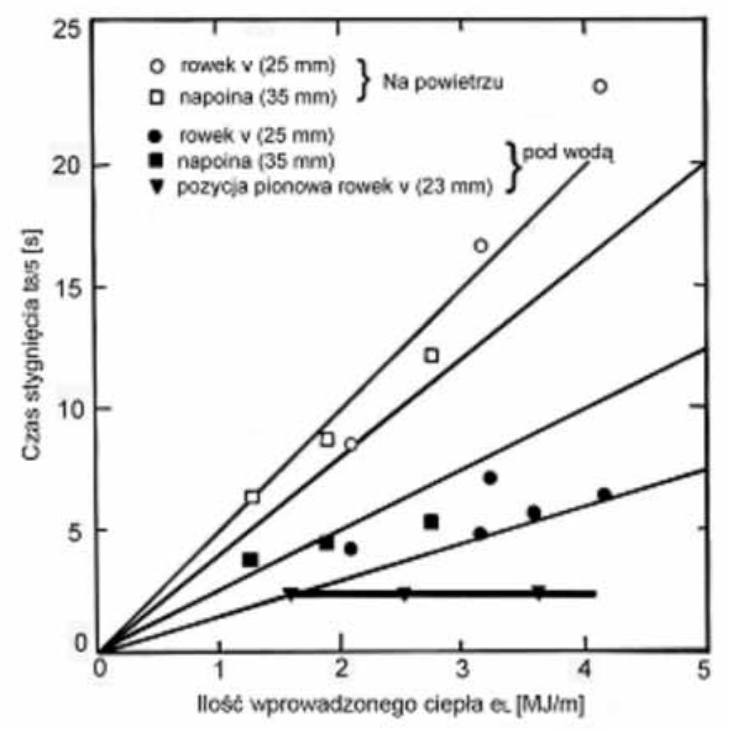

Rys. 1. Zależność czasu stygnięcia złącza od ilości wprowadzonego ciepła: $\circ$ - spawanie w powietrzu, $\bullet-$ spawanie pod wodą, 口 - napawanie w powietrzu, $\cdot-$ napawanie pod wodą, $\boldsymbol{\nabla}$ - spawanie pod wodą w pozycji pionowej [4]

Fig. 1. Effect of heat input on cooling time: $\diamond-$ welding in air, $\bullet-$ weIding under water, - - overlaying in air, $\cdot-$ overlaying under water, $\checkmark$ - welding under water in vertical position [4] 


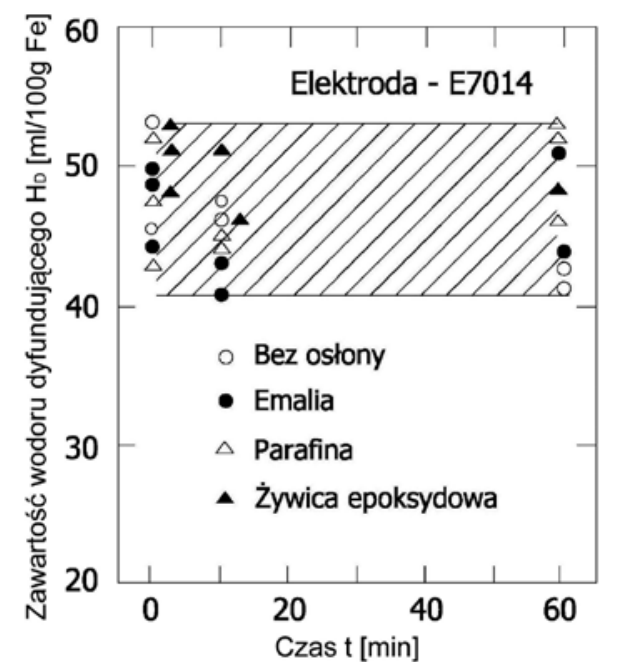

Rys. 2. Wpływ czasu przebywania elektrody w środowisku wodnym na zawartość wodoru dyfundującego [6]

Fig. 2. Effect of residence time of electrode in water environment on diffusible hydrogen content in deposited metal [6]

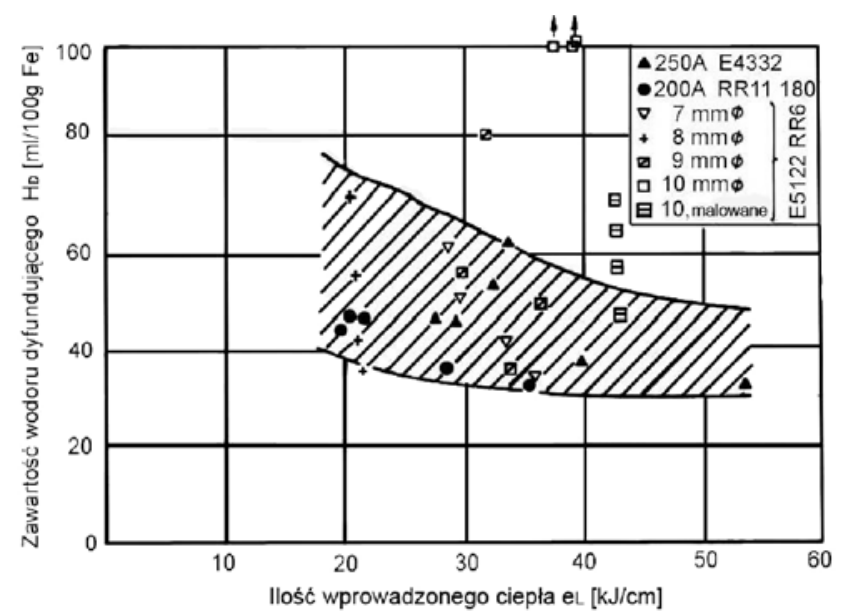

Rys. 3. Wpływ ilości wprowadzonego ciepła przy spawaniu mokrym elektrodami otulonymi na zawartość wodoru dyfundującego w stopiwie [19]

Fig. 3. Effect of heat input of MMA wet welding on diffusible hydrogen content in deposited metal [19]

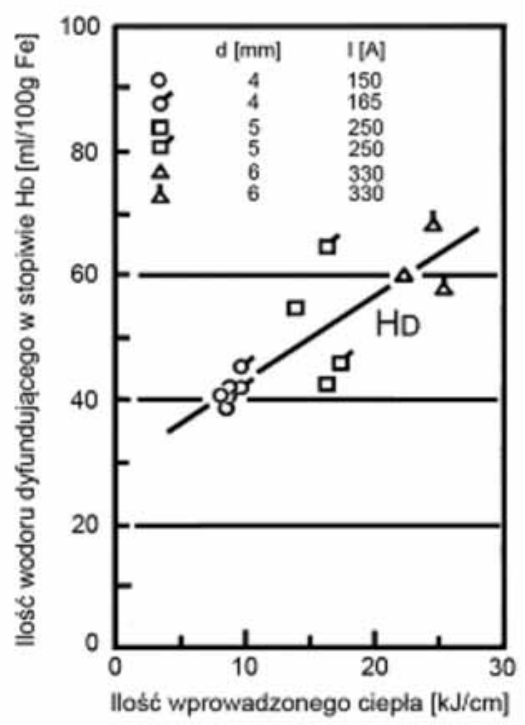

Rys. 4. Wpływ ilości wprowadzonego ciepła przy spawaniu mokrym elektrodami otulonymi na ilość wodoru dyfundujacego w stopiwie [31]

Fig. 4. Effect of heat input of MMA wet welding on diffusible hydrogen amount in deposited metal [31]

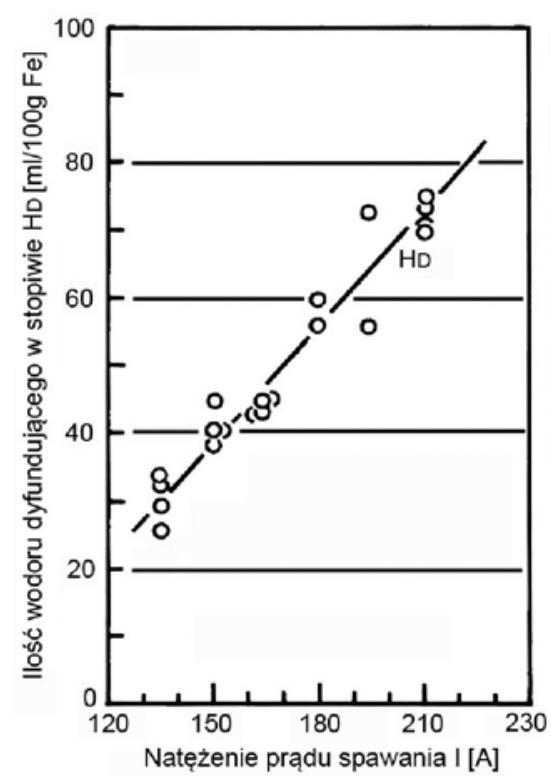

Rys. 5. Wpływ natężenia prądu spawania przy spawaniu mokrym elektrodami otulonymi na ilość wodoru dyfundującego w stopiwie [31]

Fig. 5. Effect of weIding current of MMA wet welding on diffusible hydrogen amount in deposited metal [31]

llość wodoru w stopiwie zależy również od jego składu chemicznego i rośnie wraz ze wzrostem zawartości niobu, natomiast spada, gdy zwiększa się zawartość chromu, molibdenu i wolframu [7].

Z wyników badań własnych wynika, że statystycznie istotny wpływ na zawartość wodoru dyfundującego mają następujące czynniki [14]:

- zasolenie wody,

- zanieczyszczenie elektrody węglowodorami,

- natężenie prądu spawania,

- biegunowość prądu spawania.

Wzrost zasolenia wody i spawanie z biegunowością dodatnią powodują zmniejszenie zawartości wodoru dyfundującego w stopiwie, natomiast zanieczyszczenie elektrody węglowodorami i wzrost natężenia prądu spawania wpływaja na jego wzrost. Uzyskane wyniki są częściowo (wpływ biegunowości) niezgodne z danymi literaturowymi i wymagają weryfikacji.

llość wodoru dyfundującego w stopiwie elektrod rutylowych można obliczyć z następującego równania [14]:

$$
H_{D}=55,63+0,08 \cdot I+8,25 \cdot s-2,12 \cdot z-2,28 \cdot b
$$

gdzie: $H_{D}$ - zawartość wodoru dyfundującego w stopiwie oznaczona metodą glicerynową, $\mathrm{ml} / 100 \mathrm{~g} \mathrm{Fe;} \mathrm{I} \mathrm{-} \mathrm{natężenie} \mathrm{prądu} \mathrm{spawania;} \mathrm{A,}$ s - stan elektrody (stopień zanieczyszczenia otuliny olejem); z - zasolenie wody \%o; b - biegunowość spawania.

Minimalną ilość wprowadzonego ciepła zabezpieczającą przed pęknięciami można obliczyć z równania [4]:

$$
e_{L}=200 \cdot(P-T / 600)-67
$$

gdzie: $e_{\perp}$ - ilość wprowadzonego ciepła $\mathrm{kJ} / \mathrm{cm}, \mathrm{P}=\mathrm{Ce}+\mathrm{H}_{\mathrm{D}} / 60$ + R/200000, Ce - równoważnik węgla wg MIS \%, $H_{D}$ - zawartość wodoru dyfundującego, $\mathrm{ml} / 100 \mathrm{~g} \mathrm{Fe}, \mathrm{R}$ - intensywność utwierdzenia $\mathrm{MPa}, \mathrm{T}$ - temperatura podgrzewania wstępnego, ${ }^{\circ} \mathrm{C}$. 
Badania przeprowadzone na próbkach Implant wykonane w podobnych warunkach jak próby Tekken wykazały, że naprężenia krytyczne są wyższe od granicy plastyczności badanej stali [24]. Świadczy to o odporności stali na pękanie i nie jest zgodne $z$ wynikami badań [4, 22].

Niewiele jest informacji o spawalności stali konstrukcyjnych o granicy plastyczności wyższej niż $420 \mathrm{MPa}$ spawanych pod wodą. Stale o wysokiej wytrzymałości walcowane termomechanicznie S420M i S500M spawane pod wodą elektrodami rutylowymi Omnia i zasadowymi Kryo 1 mogą powodować pęknięcia zimne w złączach doczołowych (próby Tekken) i złączach ze spoinami pachwinowymi (próby CTS) [11, 12, 32, 33]. Na rysunku 6 pokazano rozkład twardości złącza próbnego CTS ze stali S500M $(\mathrm{Ce}=0,3 \%)$ wykonanego pod wodą.

Ograniczenie skłonności do tworzenia pęknięć zimnych w SWC można osiągnąć przez zastosowanie elektrod otulonych o zawartości niklu zapewniajacej spoinie strukturę austenityczną. W takim wypadku należy jednak liczyć się z możliwością wystąpienia w spoinie pęknięć gorących i zimnych [29]. Natomiast badania metodą implant wykazały, że zastosowanie stopiwa austenitycznego spowodowało wzrost skłonności do tworzenia pęknięć zimnych w SWC [24]. Podobne spostrzeżenie było rezultatem analizy wyników prób CTS ze stali S500M spawanej elektrodami austenitycznymi Avesta 316 L/SKR [11].

Opracowane na podstawie próby Tekken kryteria bezpiecznego spawania mokrego stali niestopowych są następujące [6]: wartość równoważnika węgla materiału rodzimego $\mathrm{Ce}<0,30 \%$ i ilość wprowadzonego ciepła wyższa od $1,5 \mathrm{~kJ} / \mathrm{mm}$.

W przypadku zastosowania elektrod austenitycznych równoważnik węgla spawanej stali może być większy - nawet do 0,40\% [6].

Zmniejszenie wrażliwości na pękanie zimne można uzyskać dzięki zastosowaniu techniki ściegu odpuszczającego zapobiec zastosowaniu techniki ściegu

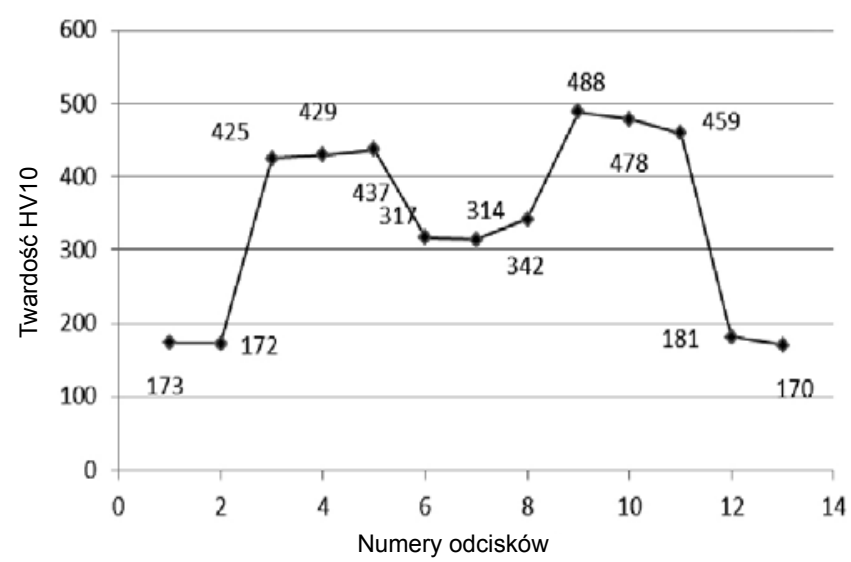

Rys. 6. Rozkład twardości złącza próbnego CTS ze stali S500M wykonanego na mokro, $\mathrm{HV}_{\max }=488$ [11]

Fig. 6. Hardness distribution across CTS joint, steel S500M welded in wet conditions, $\mathrm{HV}_{\max }=488$ [11] odpuszczającego $[22,34 \div 36]$. Skuteczność tej techniki zależy od parametrów wykonania ściegów odpuszczających, podziałki oraz czasu między wykonaniem napoin. Badania wstępne wykazały, że obniżenie twardości maksymalnej SWC poniżej $350 \mathrm{HV}$ w przypadku stali S355J2G3 można osiągnąć w szerokim $(40 \div 85 \%)$ zakresie podziałki [35]. Obecnie dzięki jednoczesnemu wykorzystaniu techniki ściegu odpuszczającego i zastosowaniu elektrod o zmodyfikowanym składzie otuliny istnieje możliwość wykonania złączy spawanych bez pęknięć w SWC ze stali o wartości równoważnika węgla $\mathrm{Ce}=0,462 \%$ i zawartości węgla $C=0,2 \%$ [34].

\section{Spawanie łukiem krytym pod topnikiem}

Strefa spawania podwodnego łukiem krytym zostaje przykryta topnikiem i żużlem, co powoduje obniżenie prędkości stygnięcia, nie dopuszczając do wzrostu twardości złącza i powstawania pęknięć. Nie stwierdzono występowania pęknięć zimnych w złączach ze stali o równoważniku węgla $\mathrm{Ce}=0,36 \%$ pomimo bardzo dużej zawartości wodoru $w$ stopiwie $(50 \mathrm{ml} / 100 \mathrm{~g} \mathrm{Fe})$. Tłumaczy się to stosunkowo długim czasem stygnięcia złączy $\left(t_{8 / 5}=15 \mathrm{~s}\right)$, co znalazło odzwierciedlenie w rozkładzie twardości złączy pokazanym na rysunku 7 [13].

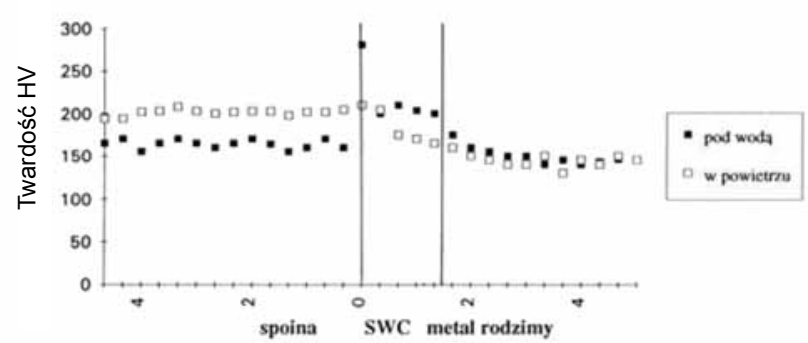

Rys. 7. Rozkład twardości w złączu doczołowym wykonanym pod wodą łukiem krytym pod topnikiem [13]

Fig. 7. Hardness distribution across butt joint, steel welded in wet conditions by submerged arc welding [13]

\section{Spawanie MIG/MAG}

Stan wiedzy związany z wrażliwością na pękanie zimne złączy wykonanych metodą MIG/MAG w warunkach mokrych jest wyjątkowo ubogi. Wynika to przede wszystkim z faktu wypierania tego procesu przez oferującą lepsze właściwości złączy metodę lokalnej komory suchej oraz spawanie mokre drutami proszkowymi samoosłonowymi [16]. Dostępne wyniki badań sugerują jednak podwyższoną skłonność do pękania zimnego złączy otrzymanych tą metodą, gdyż zawartość wodoru dyfundującego w stopiwie osiąga wartość do $30 \mathrm{ml} / 100 \mathrm{~g} \mathrm{Fe}$ [18]. 


\section{Spawanie drutami samoosłonowymi}

Spawanie mokre drutami samoosłonowymi jest procesem wykorzystywanym głównie w krajach dawnego Związku Radzieckiego. Stosunkowo liczne zastosowania tej metody świadczą o jej przydatności w remontach jednostek pływających [16]. W literaturze odnotowano rzadkie przypadki występowania pęknięć zimnych w złączach wykonanych tą metodą. Wysoka zawartość wodoru w zakresie $25 \div 44 \mathrm{ml} / 100 \mathrm{~g}$ sugeruje, że w przypadku spawania stali o wyższej wartości równoważnika węgla takie niezgodności też mogą powstawać [17]. Zgodnie $\mathrm{z}$ wykresami pokazanymi na rysunkach 8 i 9 wzrost napięcia łuku powoduje wzrost zawartości wodoru dyfundującego, natomiast

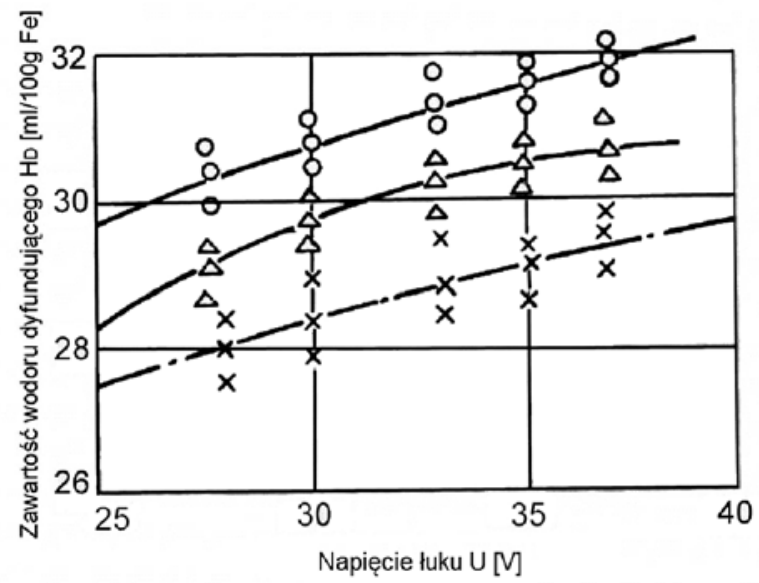

Rys. 8. Wpływ napięcia łuku FCAW-S na zawartość wodoru dyfundującego w stopiwie [16]

Fig. 8. Effect of FCAW-S voltage on diffusible hydrogen content in deposited metal [16]

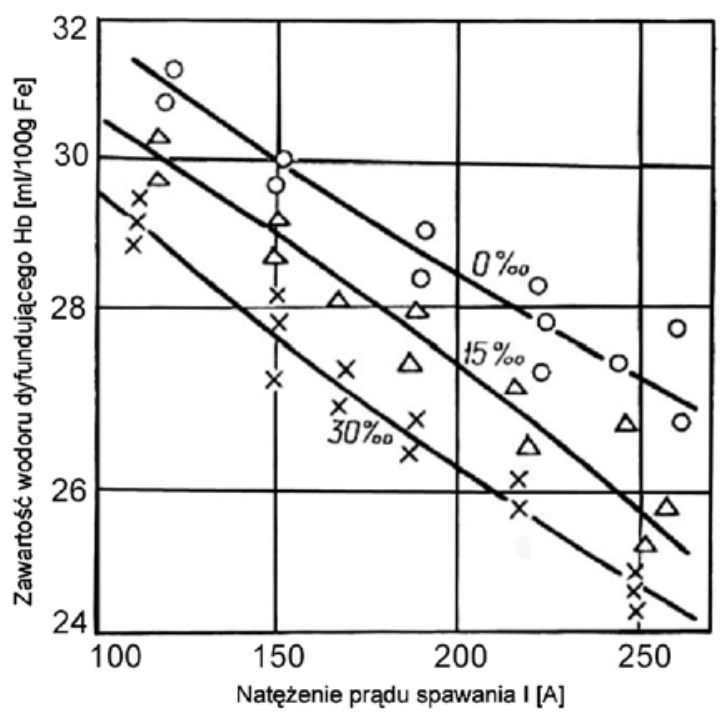

Rys. 9. Wpływ natężenia prądu spawania na zawartość wodoru dyfundującego w stopiwie [16]

Fig. 9. Effect of FCAW-S welding current on diffusible hydrogen content in deposited metal [16] zwiększanie natężenia prądu lub zasolenia wody spadek jego ilości [16]. Wyniki badań własnych wskazują, że wzrost długości wolnego wylotu drutu oraz prędkości spawania powoduje zwiększenie ilości wodoru dyfundującego, natomiast odwrotny wpływ ma zwiększenie natężenia prądu spawania, napięcia łuku i zasolenia wody [17].

\section{Spawanie suche hiperbaryczne}

Spawanie suche hiperbaryczne polegające na zastosowaniu komory, dzięki której następuje całkowite usunięcie wody z obszaru spawania, zapewnia złączom spawanym warunki technologiczne zbliżone do panujących podczas spawania w powietrzu. Najczęściej stosowana metoda spawania hiperbarycznego jest spawanie ręczne elektrodą otuloną [37]. Rzadziej stosuje się spawanie MAG, TIG i FCAW [38].

Wilgotność atmosfery gazowej, będącej potencjalnym źródłem wodoru może osiągać nawet $90 \%$ [37], a czasy stygnięcia złączy są zbliżone do czasów uzyskiwanych uzyskiwanych przy spawaniu w powietrzu.

Głębokość spawania hiperbarycznego nie wpływa na twardość maksymalną SWC złączy ze stali niskowęglowej, której wartość dochodzi do $250 \mathrm{HV}$ [37], ale ma wprost proporcjonalny wpływ na wzrost zawartości wodoru dyfundującego w stopiwie $[4,30]$. W przypadku spawania elektrodami zasadowymi stwierdzono wzrost ilości wodoru dyfundującego $z 5$ do ponad $10 \mathrm{ml} / 100 \mathrm{~g} \mathrm{Fe}$ [3]. Stąd wynika konieczność suszenia elektrod i przechowywania ich w podwyższonej temperaturze, często w atmosferze helu. Ze względu na higroskopijność otuliny, elektrody wyjęte z pojemników nie powinny przebywać w komorze hiperbarycznej dłużej niż 10 min.

Zastosowanie podgrzewania wstępnego jest w warunkach hiperbarycznych ograniczone powierzchnią stosowanych komór roboczych. Stanowi jednak skuteczną metodę obniżenia skłonności do formowania się pęknięć zimnych. Zwiększenie temperatury początkowej elementów stalowych o równoważniku węgla $0,45 \%$ spawanych metodą FCAW do $100^{\circ} \mathrm{C}$ wpłynęło na zmniejszenie twardości maksymalnej SWC z 345 do 268 HV [38].

\section{Spawanie metodą lokalnej komory suchej}

Spawanie z zastosowaniem lokalnej komory suchej jest możliwe dzięki wykorzystaniu standardowego urządzenia do spawania półautomatycznego, czyli źródła prądu, podajnika drutu elektrodowego, systemu dostarczania gazu osłonowego i uchwytu spawalniczego wyposażonego w komorę, której głównym zadaniem jest wytworzenie $w$ otoczeniu łuku 
obszaru pozbawionego wody. Konstrukcja lokalnej komory suchej pozwala na usunięcie wody $z$ jej wnętrza, osuszenie powierzchni spawanego materiału oraz ochronę jeziorka i łuku spawalniczego gazem osłonowym $[3 \div 5,8]$. Metoda ta charakteryzuje się stosunkowo niskimi kosztami i zbliżeniem warunków cieplnych i metalurgicznych spawania do panujących w powietrzu. Do wad metody zalicza się brak możliwości obserwacji procesu spawania oraz powstawanie tzw. mokrego stanu powierzchni wynikającego z niedostatecznego osuszenia spawanych elementów przez gaz osłonowy [4, 5]. Tym ostatnim zjawiskiem tłumaczy się możliwość zwiększania się ilości wodoru dyfundującego, a więc i zwiększonej skłonności do tworzenia pęknięć zimnych w porównaniu ze spawaniem w środowisku powietrznym. Na rysunku 10 pokazano fragment złącza ze stali S420M wykonanego metodą lokalnej komory suchej, w którym rozwinęło się pęknięcie w spoinie.

Wyniki doświadczeń z dowodzą, że zawartość wodoru dyfundującego w stopiwie zmniejsza się wraz ze wzrostem wydatku gazu osłonowego (rys. 11) [19]. Również zwiększenie ilości wprowadzonego ciepła powoduje zmniejszenie ilości wodoru (rys. 12).

Z wyników badań własnych wynika również, że podczas spawania lokalną komorą suchą generowana jest większa ilość wodoru dyfundującego niż

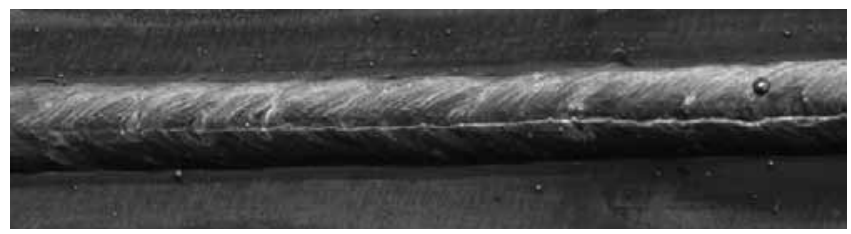

Rys. 10. Złącze doczołowe ze stali S420M wykonane metodą lokalnej komory suchej z pęknięciem zimnym w spoinie

Fig. 10. Butt joint of S420M steel made by local cavity welding with cold crack in weld

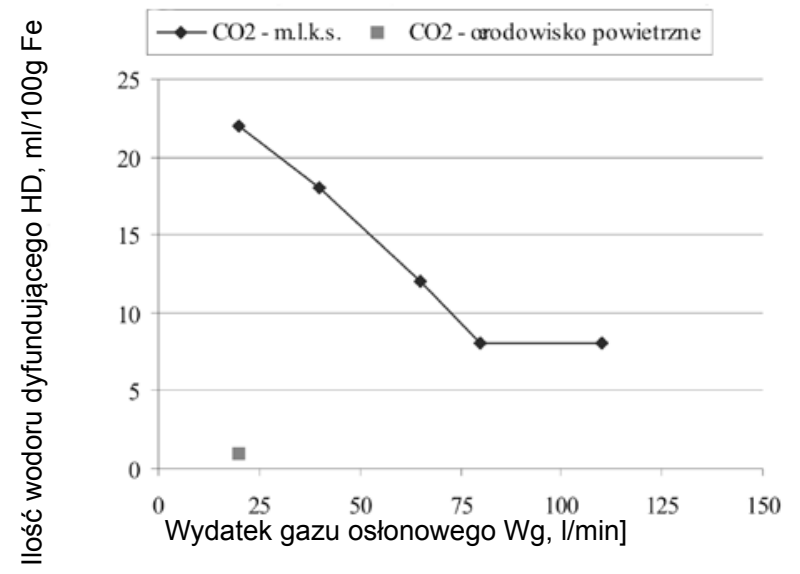

Rys. 11. Wpływ wydatku gazu osłonowego na zawartość wodoru dyfundującego w stopiwie podczas spawania metodą lokalnej komory suchej [19]

Fig. 11. Effect of shielding gas flow rate on diffusible hydrogen content in deposited metal during local cavity welding [19] w czasie spawania w środowisku powietrznym (rys. 13) [26]. W zależności od przyjętych warunków wynosi ona $5 \div 21 \mathrm{ml} / 100 \mathrm{~g} \mathrm{Fe}$ [9]. W zakresie przeprowadzonych badań nie osiągnięto poziomu ilości wodoru właściwej dla procesów niskowodorowych.

Wzrost zawartości wodoru dyfundującego w stopiwie jest powodowany przez wzrost napięcia łuku, zasolenia wody, natężenia prądu spawania i prędkości spawania. Zwiększenie długości wolnego wylotu i wydatku gazu osłonowego wpływa natomiast na wielkość wynikową w sposób przeciwny. Zależności te można przedstawić w postaci równania [9]:

$$
\begin{aligned}
H_{D}= & 2,99-0,24 \cdot I_{w}+0,02 \cdot I+0,39 \cdot U+ \\
& +4,72 \cdot V_{s p}+0,27 \cdot z-0,18 \cdot w_{g}
\end{aligned}
$$

gdzie: $H_{D}$ - zawartość wodoru dyfundującego w stopiwie oznaczona metodą glicerynową, $\mathrm{ml} / 100 \mathrm{~g} \mathrm{Fe} ; \mathrm{I}_{\mathrm{w}}$ - długość wolnego wylotu, mm; $\mathrm{I}$ - natężenie prądu spawania, $\mathrm{A} ; \mathrm{U}$ - napięcie łuku, V; $\mathrm{V}_{\mathrm{sp}}$ - prędkość spawania, cm/s; z - zasolenie wody, \%o; $\mathrm{w}_{\mathrm{g}}$ - wydatek gazu osłonowego, $1 / \mathrm{min}$

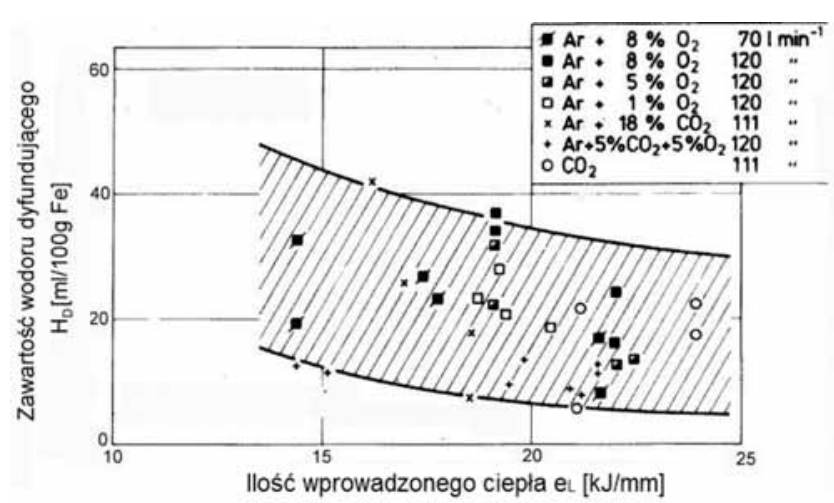

Rys. 12. Wpływ ilości wprowadzonego ciepła na zawartość wodoru dyfundującego w stopiwie podczas spawania metodą lokalnej komory suchej [19]

Fig. 12. Effect of heat input of local cavity welding on diffusible hydrogen content in deposited metal [19]

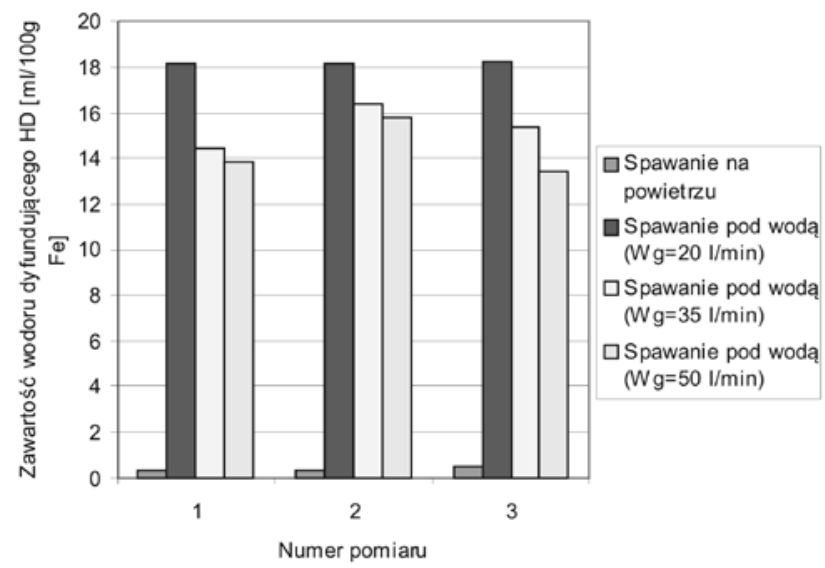

Rys. 13. Zawartość wodoru dyfundującego w stopiwie przy spawaniu metodą lokalnej komory suchej w osłonie $\mathrm{CO}_{2}$; ilość wprowadzonego ciepła $20 \mathrm{~kJ} / \mathrm{cm}$ [39]

Fig. 13. Diffusible hydrogen content in deposited metal during local cavity welding, shielding gas $-\mathrm{CO}_{2}$, heat input $20 \mathrm{~kJ} / \mathrm{cm}$ [39] 
Rzeczywisty cykl cieplny zarejestrowany podczas spawania pod wodą metodą lokalnej komory suchej pokazany na rysunku 14 ma charakterystyczny punkt na krzywej stygnięcia będący skutkiem chłodzącego działania wody i wskazujący na zwiększenie szybkości stygnięcia w porównaniu ze spawaniem powietrzu.

Twardość maksymalna SWC zależy od składu chemicznego stali i parametrów spawania. Na twardość złączy wpływa również rodzaj gazu osłonowego. Przy zastosowaniu gazu $\mathrm{C} 1$ otrzymuje się niższe wartości twardości niż w przypadku spawania w osłonie gazu M21 [41].

Wartość znormalizowanych naprężeń krytycznych z próby implant dla złączy ze stali S355J2G3 wykonanych metodą lokalnej komory suchej wynosi $\alpha=0,73$, co interpretuje się jako częściową skłonność do tworzenia pęknięć zimnych [42]. Wyniki badań twardości złączy próbnych badanych zgodnie z zasadą pokazaną na rysunku 15 potwierdzają otrzymane rezultaty, gdyż twardość maksymalna SWC jest praktycznie równa przyjmowanej jako graniczna wartości $350 \mathrm{HV}$ (rys. 16).

W badanych złączach stwierdzono występowanie pęknięć zimnych o nieregularnym kształcie biegnących wzdłuż linii wtopienia [43]. W przeważającej części występowały w płaszczyźnie prostopadłej do osi. Wykryto również liczne rozgałęzione mikropęknięcia. W obszarze SWC badanych próbek zidentyfikowano strukturę hartowniczą. Badania fraktograficzne

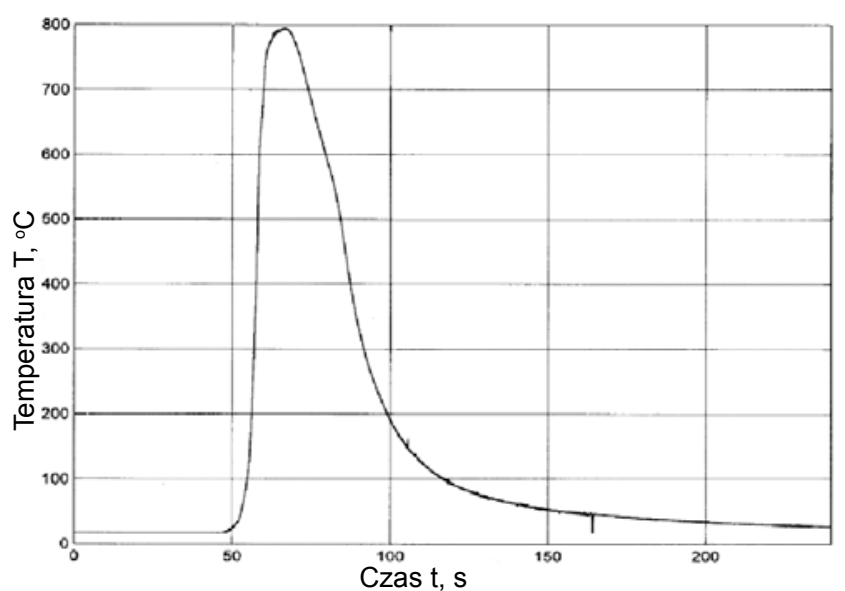

Rys. 14. Cykl cieplny spawania metodą lokalnej komory suchej [40] Fig. 14. Thermal cycle of local cavity welding [40]

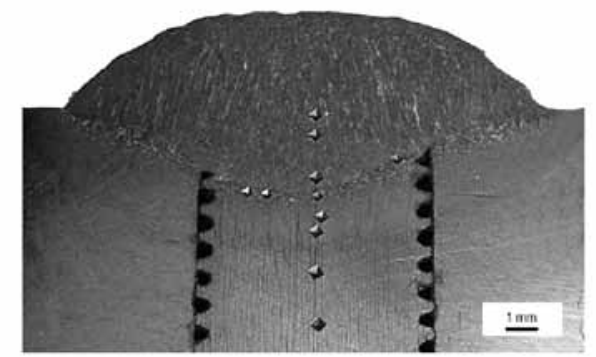

Rys. 15. Zgład makroskopowy złącza implant po pomiarze twardości [26]

Fig. 15. Macroscopic cross section of implant joint after hardness test [26] przełomów pęknięć zimnych potwierdziły, że powstałe pęknięcia mają charakter zarówno transkrystaliczny, jak i międzykrystaliczny. W strukturze hartowniczej pęknięcia przebiegają głównie transkrystalicznie. Wykryte pęknięcia mają nieregularny kształt i są silnie rozgałęzione. Przykładową fotografię przełomu pęknięcia zimnego pokazano na rysunku 17.

Podobnie jak w czasie spawania mokrego również w przypadku spawania lokalną komorą suchą poprawienie spawalności można uzyskać stosując technikę ściegu odpuszczającego. Twardość maksymalna SWC napoin na stali S355J2G3 po zastosowaniu napawania odpuszczającego nie przekraczała 250 HV10 [36].

Podsumowując stan wiedzy dotyczący tworzenia pęknięć zimnych złączy wykonanych metodą lokalnej komory suchej, należy zauważyć, że informacje pochodzące $z$ literatury są sprzeczne. $Z$ jednej strony podkreśla się zaletę metody, jaką jest zachowywanie

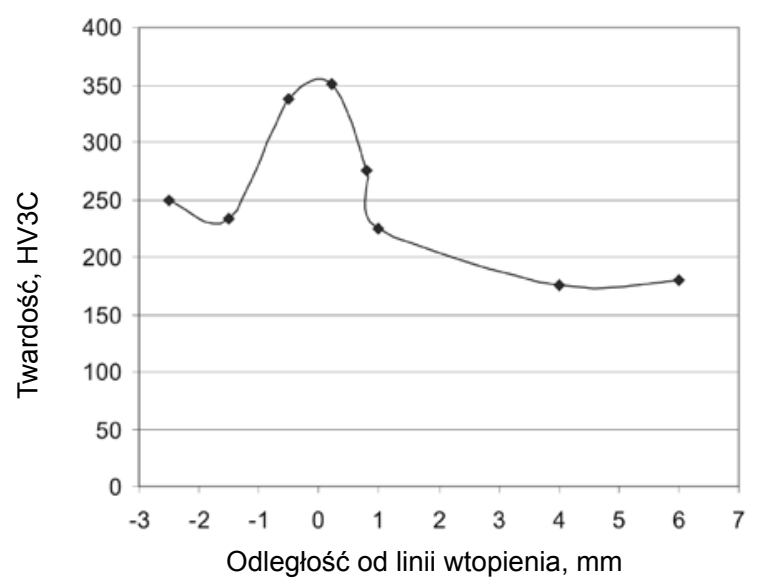

Rys. 16. Rozkład twardości złącza implant; stal S355J2G3, $\mathrm{HV}_{\text {max }}=351[26]$

Fig. 16. Hardness distribution across implant joint, steel S355J2G3, $\mathrm{HV}_{\text {max }}=351[26]$

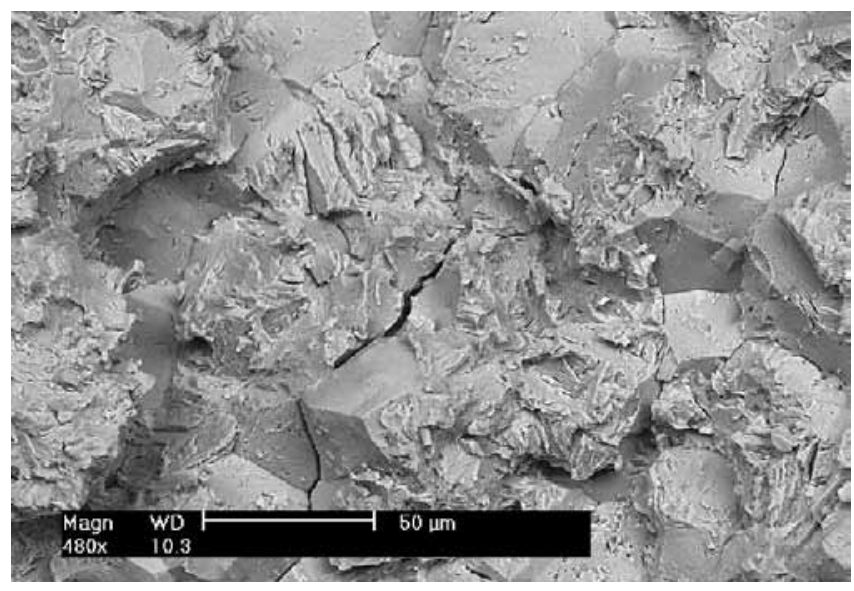

Rys. 17. Pęknięcie zimne w złączu implant. Przełom kruchy transkrystaliczny i częściowo międzykrystaliczny. W centralnej części zdjęcia widoczne międzykrystaliczne pęknięcie prostopadłe do powierzchni przełomu [43]

Fig. 17. Cold crack in implant joint. Transgranular and intergranular fracture regions. Intergranular crack in the central part of photograph [43] 
warunków spawania zbliżonych do spawania na powietrzu, a z drugiej wyniki badań: twardości (o wartościach nawet do $470 \mathrm{HV}$ sugerujących wytwarzanie się struktury martenzytycznej) i oznaczania zawartości wodoru dyfundującego wskazują na możliwość powstawania pęknięć zimnych.

\section{Podsumowanie}

Najpoważniejszym ograniczeniem spawalności stali w przypadku spawania w środowisku wodnym jest zwiększona skłonność do formowania się pęknięć zimnych, przy czym źródeł takiego stanu rzeczy upatruje się w zwiększonej zawartości wodoru dyfundującego oraz krótszych czasach stygnięcia. Warunki takie wpływają niekorzystnie na czynniki odpowiedzialne za mechanizm pękania na zimno.

Większość wyników badań wskazuje na zwiększoną skłonność do tworzenia pęknięć zimnych złączy wykonanych w środowisku wodnym. W przypadku spawania mokrego pęknięcia zimne tworzą się w złączach ze stali węglowych o $\mathrm{Ce}>0,35 \%$ i w stalach o podwyższonej wytrzymałości. Wyniki badań wskazują również na wysoką skłonność do powstania pęknięć zimnych spoin stali walcowanych termomechanicznie. Spawanie w warunkach suchych izobarycznych nie stwarza problemów związanych z powstawaniem pęknięć zimnych. Nieprzestrzeganie zaleceń dotyczących specjalnego traktowania (suszenie i przechowywanie) elektrod otulonych może natomiast skutkować pękaniem złączy wykonanych w komorach hiperbarycznych. Spawanie metodą lokalnej komory suchej nie wywołuje pęknięć w stali niskowęglowej i powoduje wzrost wrażliwości na pękanie zimne stali o podwyższonej wytrzymałości do poziomu skłonności częściowej, pomimo zastosowania wysokich wartości wydatku gazu osłonowego i ilości wprowadzonego ciepła.

Zapobieganie tworzeniu się pęknięć zimnych w przypadku spawania pod wodą jest trudniejsze niż przy spawaniu w powietrzu. Możliwości ograniczenia zawartości wodoru dyfundującego w złączu są znacznie mniejsze. Suszenie i pokrywanie powłokami elektrod otulonych praktycznie (poza spawaniem hiperbarycznym) nie daje znaczących efektów. Stosowanie jako gazu osłonowego $\mathrm{CO}_{2}$, nawet o wydatku przekraczającym $50 \mathrm{l} / \mathrm{min}$, nie pozwala na obniżenie ilości wodoru w stopiwie poniżej $10 \mathrm{ml} / 100 \mathrm{~g} \mathrm{Fe}$. Zastosowanie spoiwa austenitycznego minimalizuje ryzyko występowania pękania zimnego, jednak powoduje formowanie się pęknięć gorących. Spawanie w warunkach mokrych znacznie utrudnia zastosowanie podgrzewania wstępnego. Możliwość modyfikacji cyklu cieplnego spawania przez dobór parametrów spawania jest ograniczona przez węższy zakres stabilności łuku.

Zjawiska odpowiadające za zwiększoną skłonność do tworzenia pęknięć zimnych podczas spawania pod wodą nie są dostatecznie rozpoznane. Analiza literatury wykazuje istotne luki i sprzeczności w informacjach dotyczących odporności złączy wykonanych pod wodą na formowanie się pęknięć zimnych. Dotychczasowe badania dotyczyły głównie spawania mokrego, które jest najczęściej stosowane.

Wprawdzie podstawowym ograniczeniem spawalności stali w środowisku wodnym jest skłonność do powstawania pęknięć zimnych, jednak z praktyki oraz analizy literatury wynika, że drugim poważnym zagrożeniem jest zjawisko pękania gorącego.

\section{Wnioski}

Głównym ograniczeniem spawalności stali w środowisku wodnym jest skłonność do pękania zimnego. Nasilenie tego zjawiska dla danego gatunku stali zależy od zastosowanej metody, warunków i parametrów spawania.

Jeżeli złącze wykonywane jest pod wodą, zawartość wodoru dyfundującego wzrasta znacząco w porównaniu ze spawaniem w środowisku powietrznym.
Metoda ściegu odpuszczającego stanowi skuteczną metodę poprawy spawalności stali o podwyższonej wytrzymałości w środowisku wodnym.

Stan wiedzy dotyczący skłonności złączy spawanych wykonanych pod wodą do tworzenia pęknięć zimnych jest w wielu przypadkach niekompletny i wymaga dodatkowych badań. Dotyczy to zwłaszcza stali konstrukcyjnych o podwyższonej i wysokiej wytrzymałości.

\section{Literatura}

[1] Bailey N.: Weldability of ferritic steels. Abington Publishing, Abington Hall, Cambridge, England 1994.

[2] Butnicki S.: Spawalność i kruchość stali. Wydawnictwa Naukowo-Techniczne, Warszawa 1991.

[3] Cotton H. C.: Welding under water and in the splash zone - a review. Proceedings of the International Conference „Underwater Welding", Trondheim, Norway 1983.
[4] Christensen N.: The metallurgy of underwater welding. Proceedings of the International Conference „Underwater WeIding", Trondheim, Norway 1983.

[5] Łabanowski J., Fydrych D., Rogalski G.: Underwater Welding - a review. Advances in Materials Science 3/2008. 
[6] Lesiński K.J.: Metalurgiczne aspekty spawania pod wodą. Materiały konferencji naukowo-technicznej „Problemy cięcia i spawania pod wodą", ITMMiS, Gdańsk 1985.

[7] Ibarra S., Grubbs C.E., Liu S.: State of the art and practice of underwater wet welding of steel. International workshop on underwater welding of marine structures. New Orleans, USA 1994.

[8] Zhang X., Ashida E., Shono S., Matsuda F.: Effect of shielding conditions of local dry cavity on weld quality in underwater Nd:YAG laser welding. Journal of Materials Processing and Technology. Vol. 174, issues 1-3, May 2006.

[9] Fydrych D., Rogalski G.: Wpływ warunków spawania podwodnego metodą lokalnej komory suchej na zawartość wodoru dyfundującego w stopiwie. Przegląd Spawalnictwa $11 / 2009$.

[10] Ambroziak A., Gul B.: Podwodne zgrzewanie tarciowe uplastycznionym trzpieniem stalowym złączy zakładkowych (FHPP). Przegląd Spawalnictwa 9-10/2006.

[11] Bartnicki K.: Ocena skłonności do tworzenia pęknięć zimnych stali spawanej pod wodą. Praca dyplomowa stopnia inżynierskiego realizowana pod kierunkiem dr. inż. Dariusza Fydrycha. Politechnika Gdańska, Gdańsk 2012.

[12] Kurzawa P.: Spawalność stali wysokiej wytrzymałości spawanej pod wodą. Praca dyplomowa stopnia inżynierskiego realizowana pod kierunkiem dr. inż. Dariusza Fydrycha. Politechnika Gdańska, Gdańsk 2012.

[13] Hasai A., Suga Y., Kishi S.: On underwater submerged - arc welding (the 2nd report). Transactions of the Japan Welding Society, $1 / 1980$.

[14] Fydrych D., Rogalski G.: Wpływ warunków spawania mokrego elektrodą otuloną na zawartość wodoru dyfundującego w stopiwie. Przegląd Spawalnictwa 2/2008.

[15] Medeiros R.C., Liu S.: A predictive electrochemical model for weld metal hydrogen pickup in underwater wet welds. Journal of Offshore Mechanics and Arctic Engineering, 11/1998.

[16] Kononenko W. Ya.: Effect of water salinity and mechanized underwater welding parameters on hydrogen and oxygen content of weld metal. Proceedings of the International Conference „Welding Under Extreme Conditions”, Helsinki, Finland 1989.

[17] Fydrych D., Rogalski G.: Badania procesów spawania pod woda. Sprawozdanie z pracy badawczej BW 014693 08, Politechnika Gdańska, Gdańsk 2010.

[18] Hoffmeister H., Kuster K.: Process variables and properties of underwater wet shielded metal arc laboratory welds. Proceedings of the International Conference „Underwater Welding”, Trondheim, Norway 1983.

[19] Hoffmeister H., Kuster K.: Process variables and properties of wet underwater gas metal arc laboratory and sea welds of medium strength steels. Proceedings of the International Conference „Underwater Welding”, Trondheim, Norway 1983

[20] Matsuda K., Masumoto I., Hasegawa M.: Study on the crack sensitivity of mild steel welded joint by underwater welding. Proceedings of the International Conference „Joining of Metals - 2", Helsingor, Denmark 1984.

[21] Ozaki H., Naiman J., Masubuchi K.: A study of hydrogen cracking in underwater steel welds. Welding Journal, 8/1977.

[22] Fydrych D., Rogalski G., Łabanowski J.: Spawalność stali o podwyższonej wytrzymałości w warunkach podwodnych. Przegląd Spawalnictwa 11/2011.

[23] Bohme D., Eisenbeis C.: Investigation into the credibility of the implant test when used to assess the cold cracking sensitivity of underwater wet welds. Proceedings of the International Conference „Welding Under Extreme Conditions”, Helsinki, Finland 1989.

[24] Brink S.H., Boltje G.W.: Cold cracking susceptibility of weIds obtained by wet underwater welding. Proceedings of the International Conference „Underwater Welding”, Trondheim, Norway 1983.
[25] Yara H., Makishi Y., Kikuta Y., Matsuda H.: The TRC test for high strength steel in wet underwater welding. Transactions of the Japan Welding Society, 4/1988.

[26] Fydrych D.: Wpływ warunków spawania na skłonność do tworzenia pęknięć zimnych przy spawaniu pod wodą. Praca doktorska, Politechnika Gdańska, Gdańsk 2005.

[27] Ando S., Asahina T.: A study on the metallurgical properties of steel welds with underwater gravity welding. Proceedings of the International Conference „Underwater Welding”, Trondheim, Norway 1983.

[28] Skorupa A., Bal M.: Wpływ środowiska wodnego na jakość połączeń spawanych pod wodą. Przegląd Spawalnictwa 3/1986.

[29] Tasak E., Bal M.: Struktura i właściwości spoin wykonanych elektrodami otulonymi pod wodą. Przegląd Spawalnictwa 1-2/1985.

[30] Suga Y., Hasui A.: Effect of pressure on mechanical properties of welded joints - on gravity arc welding under high pressure atmosphere. Transactions of the Japan Welding Society, 2/1991.

[31] Suga Y.: Effect of diffusible hydrogen on mechanical properties of underwater welded joints - study on improving the mechanical properties of underwater welded joints (the 1st report). Transactions of the Japan Welding Society, 10/1985.

[32] Kostro $Ł .:$ Podwodne spawanie stali o wysokiej wytrzymałości. Praca dyplomowa stopnia inżynierskiego realizowana pod kierunkiem dr. inż. Dariusza Fydrycha. Politechnika Gdańska, Gdańsk 2011.

[33] Jakóbczak P.: Ocena spawalności stali spawanej metodą mokrą. Praca dyplomowa stopnia inżynierskiego realizowana pod kierunkiem dr. inż. Dariusza Fydrycha. Politechnika Gdańska, Gdańsk 2011.

[34] Grubbs C. E.: Joint industry underwater welding development program. Phase I - final report. Global Divers \& Contractors Inc., Colorado School of Mines, 1995.

[35] Fydrych D., Łabanowski J.: Zastosowanie techniki ściegu odpuszczającego w warunkach spawania mokrego. Prace Naukowe Politechniki Warszawskiej. Seria: Mechanika. Warszawa 2012 (w druku).

[36] Sawicki S.: Spawanie podwodne metodą lokalnej komory suchej. Praca dyplomowa stopnia magisterskiego realizowana pod kierunkiem dr. inż. Dariusza Fydrycha. Politechnika Gdańska, Gdańsk 2011.

[37] Skorupa A., Masłowski A., Bal M.: Wytrzymałość połączeń spawanych pod wodą metodą hiperbaryczną. Przegląd Spawalnictwa 3/1996.

[38] Thomas D. B. J. User's requirements and control of activities. Proceedings of the International Conference „Underwater Welding", Trondheim, Norway 1983.

[39] Walczak W., Fydrych D.: Skłonność złączy wykonanych pod wodą do tworzenia pęknięć zimnych. Prace Naukowe Politechniki Warszawskiej. Seria: Mechanika z. 215. Warszawa 2006.

[40] Rogalski G.: Pomiary cykli cieplnych przy spawaniu pod wodą. Prace Naukowe Politechniki Warszawskiej. Seria: Mechanika. Warszawa 2012 (w druku).

[41] Rogalski G., Fydrych D.: Wpływ parametrów spawania pod wodą na twardość złączy. Prace Naukowe Politechniki Warszawskiej. Seria: Mechanika z. 230. Warszawa 2010.

[42] Fydrych D., Kozak T.: Effect of welding conditions on susceptibility to cold cracking of underwater welded joints. Proceedings of International Conference "Wissenschaft fur die Praxis", Bremen, Germany 2006.

[43] Fydrych D., Kozak T.: Underwater welded joint properties investigation. Advances in Materials Science 4/2009. 